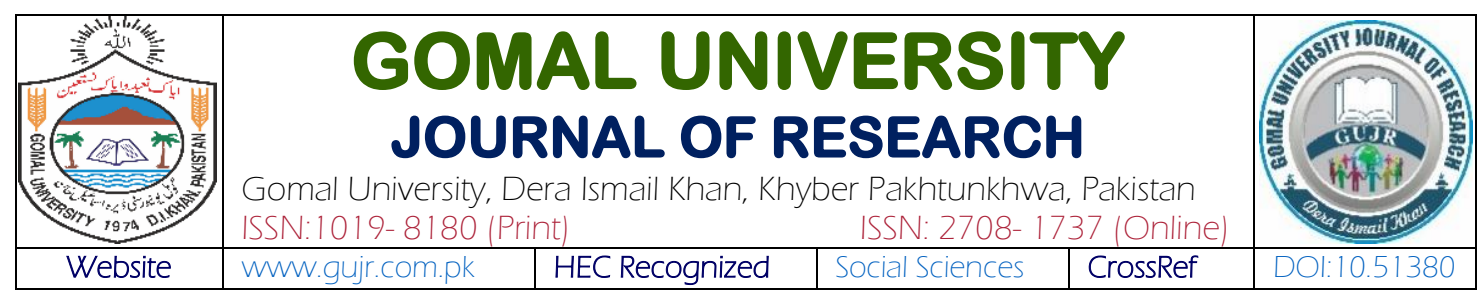

\title{
AN INVESTIGATION ON ROLE OF GREEN HUMAN RESOURCE MANAGEMENT PRACTICES ON SUSTAINABLE DEVELOPMENT OF ORGANIZATIONS
}

\author{
Fahad Albejaidi \\ Health Administration, College of Public Health \& Health Informatics, Qassim University, \\ SAUDI ARABIA
}

\begin{tabular}{|c|c|}
\hline KEY & $\mathrm{ACT}$ \\
\hline Green Recruitmer & \multirow{3}{*}{ 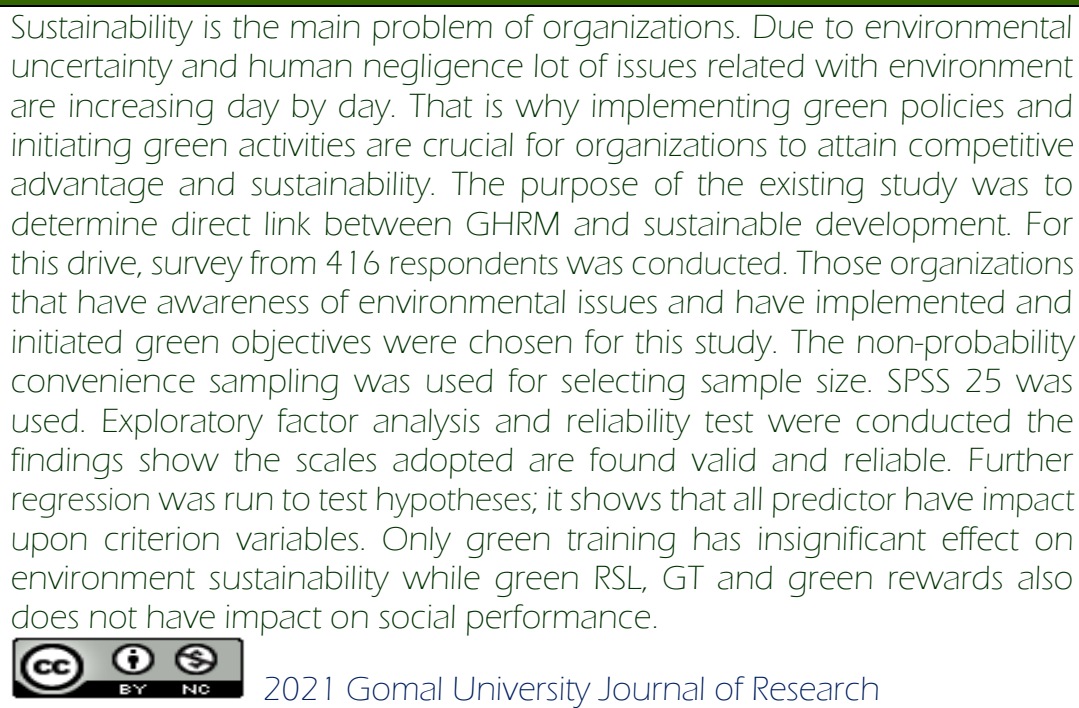 } \\
\hline Article History & \\
\hline f Submission: & \\
\hline Corresp & Albejaidi: f.alonazy@qu.edu.sa \\
\hline $\mathrm{DOI}$ & \\
\hline
\end{tabular}

\section{INTRODUCTION}

Excessive misuse and waste of natural resources by human being and industries has brought the need for idea of sustainable development. Now saving the natural resources and reducing the wastage for future is the primary purpose of organizations (Mtutu \& Thondhlana, 2016). The concept of sustainable development not only focus on economic needs and goals but also covers, social, environmental and ecological requirements (Bombiak \& Kluska, 2018). The concept of sustainable development is getting much attention globally. This idea was brought forward in order to protect environment due to negligence of human behavior. Sustainable development has introduced new methods and techniques of management, administration and operations of the organizations in an environment friendly way and it has been recognized internationally 
and at national levels (Borys, 2015). This is also called triple bottom line principle (TBLP). It has three dimensions economic looks after the monetary matters, environment factor is taking care of natural resources and social factor is about taking care of employees and well-being of society (Kim, 2018). In this connection, there are several theories, approaches and models have been introduced to explain the green human resource management practices (GHRM). One of them was resource based view theory but it was criticized by Hart (1995) and the main point of criticism was that, it has overlooked environment factor, therefore new theory was introduced that was called the natural resource based view theory (NRBV) to explain the subject matter in depth.

There is still a gap exist in literature to fill this gap this study has tried to investigate the role of GHRM practices on sustainable development of organizations. There are some theories, approaches and models have been introduced to explain the green human resource management practices (GHRM). The health practitioners, pharmacists, services organizations, and others can take benefits from the current study; it is helpful for academicians, researchers and policy makers and can save the natural resources and their degradation for the future generations. Previously organizations were product and profit oriented now firms are customers oriented. Customers are ready to pay high price for eco-friendly products and they are showing more interest for eco -friendly products and services. In Asia, organizations are taking interest in initiating green objectives but still there is limited empirical evidence available in Middle East countries, this gap needs to be filled through lens of NRBV. Previous studies conducted on manufacturing firms but Health organizations were overlooked and health care organizations need to handle lot of hospital waste. It has direct impact on human health and environment. The objectives are as follows:

- Is there any influence of green recruitment and selection on sustainable development?

- Does green training and development have impact upon the sustainable development?

- Is there any role performed by green performance evaluation on sustainable development?

- Does green rewards have effect on the sustainable development

\section{LITERATURE REVIEW}

It is reported in past studies that GHRM practices help organizations to obtain sustainability (Schaltegger \& Burritt, 2018). That is reason more and more organizations are initiating green activities to get better performance. GHRM is element of sustainable SHRM practices (Mazur, 2015). In this connection, the aim of the GHRM is to add environmental and ecological factor in all functions of human resource while recruitment and selection to training, rewards and evaluation. In this regard, the organizations are interested to select those employees who have awareness about environmental issues and they are willing to help firms to reduce ecological issues.

\section{Green Recruitment \& Selection}

This implies that candidates during process of short listing, recruitment and selection should be aware that the job description, roles and responsibilities includes to work on reducing the environmental issues. In this connection, the organizations with green initiatives and green the objectives are successful in attracting and retaining talented staff for long term. Employees feel proud to be associated with ethical firms who prefer to sustain eco balance. Previous studies have reported significant impact of green recruitment and selection on sustainable development 
(Yusliza, Yong, Tanveer, Ramayah, Faezah \& Muhammad, 2020; Yong, Yusliza, Ramayah, Jabbour, Sehnem \& Mani, 2019). Thus, as per the hints of existing literature, it is hypothesized that:

\section{Green Training}

Training add values and meaning to job at workplace. When organizations invest on training of their work force basically they are adding values and skills of their employees, they are raising awareness and importance of green activities to save and protect the environment. Employees knows that training required huge budget therefore they feel motivated, satisfied and want to be affiliated with existing firm for long time, they are proud member of ethically and socially responsible firm (Shahzad, Kumar, Zakaria \& Hurr, 2017). In this connection, it is evident from the past studies' literature (Yusoff, Omar, Zaman \& Samad, 2019; Anwar, Mahmood, Yusliza, Ramayah, Faezah \& Khalid, 2020) that green training is significantly related with sustainability therefore:

\section{Green Performance Assessment}

Managers in organizations should clearly communicate their objectives to employees and provide them all necessary resources and training so that employees help organizations to achieve their green objectives. The desired output must be compared with the delivered output of employees and on the basis of comparison managers, leaders; directors should evaluate performance of employees. It is very sensitive matter because performance evaluation needs lot of experience and knowledge. If managers did some mistake while evaluating their employees they might lose competent and hard working employees. it is crucial for managers to provide feedback to employees and help them to overcome their mistakes in future performance (Mas, 2019). It is revealed that green performance evaluation is related with sustainable development (Mtutu, 2015).

\section{Green Rewards}

Rewards are very important factor to achieve competitive advantage and high performance. it increases motivation of employees to work harder for organizational objectives. Upon successful completion of green tasks organizations should provide the employees with rewards such as flexible promotion, flexible working hours, bonuses, fringe benefits, perks and other facilities an thus helps to achieve its green goals (Taylor \& Vachon, 2018). If the organizations do not fulfill promise it leads to distrust, dissatisfaction demotivation and lower productivity. Alkhateeb (2018) argued that the GR are directly related with the SD consequently following hypotheses is postulated:

H1: Green HRM (GR\&S, GT\&D, GPA and GR) significantly related with economic performance H2: Green HRM (GR\&S, GT\&D, GPA \& GR) significantly related with environmental performance H3: Green HRM (GR\&S, GT\&D, GPA, and GR) directly related with the social performance

\section{Sustainable Development}

This idea was forts presented in 1987 by Brundtland in world commission on environment and development. Due to increase in industrialization and revolution in manufacturing sector many natural resources such as water, energy, paper, etc were wasted and due to the negligence of this human behavior lot of ecological issues were raised. That's why the new and novel concept of sustainable development was introduced (Zhao, Liu \& Sun, 2020). In developed nations firms are now aware and taking care of environment by implementing green activities. In developing 
nations and economies it is still ignored area and firms need awareness and someone has to highlight the importance of and significance of the subject matter. The change in climate, global warming, and clean drinking water issues, large amount of leakage of gases during production process has raised the importance of sustainability. It is imperative for the management and administration of the organizations prefer to hire those employees who are well aware about the environmental protection. In this connection, in past organizations focus on products and profits now organization should change their perspective from product to consumers (Sehnem, 2019).

Figure 1

Theoretical Framework

Theoretical Framework

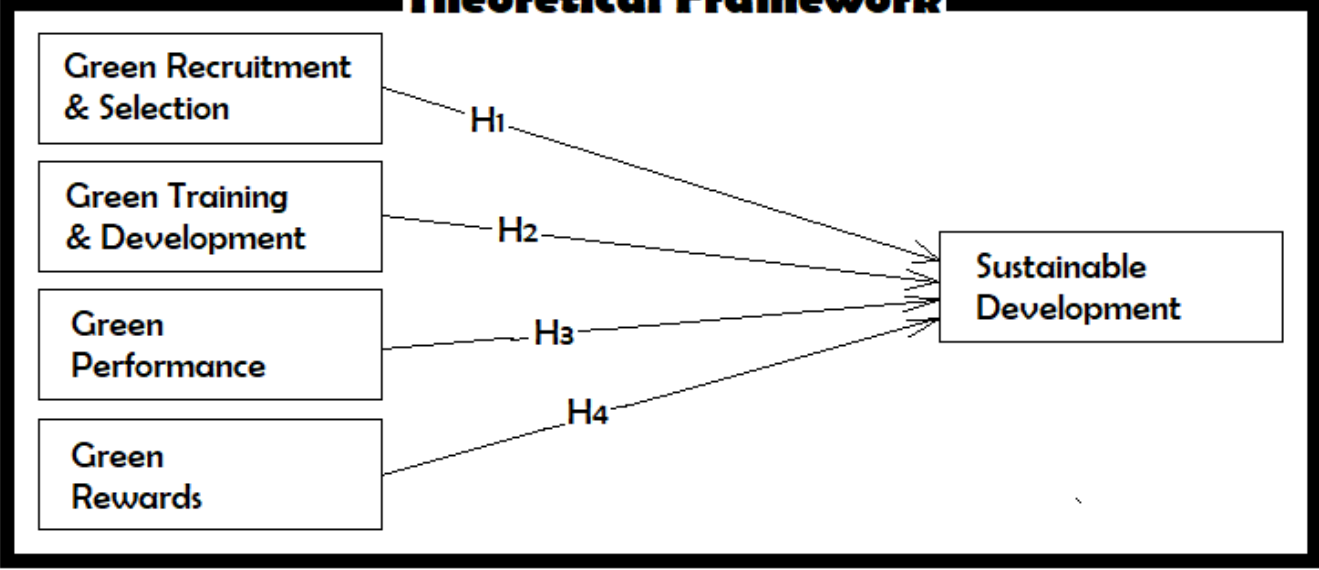

\section{Natural Resource Based View Theory (NRBV)}

Hart (1995) introduced the theory by criticizing the RNV theory. RBV theory focuses on human resources and their importance and claimed that HR is the assets of organizations. In this regard, the theory ignored the environmental aspect that is why Hart added natural resources and their important by extending the resource based view theory and introduced natural resource based view.

\section{RESEARCH METHODOLOGY}

For the current study quantitative survey design was conducted. Deductive approach was used. The current study got support the development of knowledge on basis of positivism philosophy (Sekaran, 2016). Populations of the study were health care organizations in Qassim region of Saudi Arabia. The non-probability sampling and convenience sampling technique was used to select the sample size. Total 500 questionnaires were distributed among respondents and 416 completed surveys were used in the analyses. Thus, the response rate in this study was $83.2 \%$ respectively. All the scales were adopted from previous studies (Yong et al., 2019). A benefit of conducting surveys includes low cost, time saving. Population of the current study includes doctors, nurses, medical staff, laboratory in charge, HR directors, chief executive officers, HR managers of healthcare institutions, public and private organizations, pharmaceutical, etc. those organizations who have awareness and initiated green activities were selected. Non-probability 


\section{Albejaidi ... An Investigation on}

sampling technique and convenience was used. 416 completed questionnaires were used in the analysis.

\section{Measures}

There are 15 items of sustainable development, five items for each construct i.e. (economic, social \& environmental) (Yong et al., 2019). Total 12 items for GHRM practices. Here are four items for recruitment and selection, three for training, three for evaluation and two for reward (Yusliza, Yong, Tanveer, Ramayah, Faezah \& Muhammad, 2020). Items were measured on 7-point scale.

\section{Data Analysis}

The reliability and validity was checked by Cronbach alpha and exploratory factor analysis. For testing of hypotheses correlation and multiple regression was used. All ethical steps were considered before data collection permission as obtained from relevant officials. It was make sure that data would be kept confidential and no one would be harm such as reputation of organizations and individuals.

\section{Table 1}

Measurement Model

\begin{tabular}{|c|c|c|c|c|c|}
\hline Variable & Items & $\begin{array}{l}\text { Loadings } \\
\end{array}$ & AVE & CR & Alpha \\
\hline \multirow{13}{*}{ GHRM } & RS1 & 0.927 & \multirow{4}{*}{0.641} & \multirow{4}{*}{0.875} & \multirow{13}{*}{0.813} \\
\hline & RS2 & 0.853 & & & \\
\hline & RS3 & 0.740 & & & \\
\hline & RS4 & 0.656 & & & \\
\hline & GT1 & 0.647 & \multirow{4}{*}{0.541} & \multirow{4}{*}{0.778} & \\
\hline & GT2 & 0.818 & & & \\
\hline & GT3 & 0.731 & & & \\
\hline & GPE1 & 0.849 & & & \\
\hline & GPE2 & 0.622 & \multirow[t]{2}{*}{0.454} & \multirow[t]{2}{*}{0.705} & \\
\hline & GPE3 & 0.505 & & & \\
\hline & GR1 & 0.894 & \multirow[t]{3}{*}{0.701} & \multirow[t]{3}{*}{0.824} & \\
\hline & GR1 & 0.777 & & & \\
\hline & EP1 & 0.928 & & & \\
\hline & EP2 & 0.926 & & \multirow{4}{*}{0.898} & \\
\hline & EP3 & 0.870 & \multirow[t]{3}{*}{0.647} & & \\
\hline & EP4 & 0.639 & & & \\
\hline & EP5 & 0.591 & & & \\
\hline & ENP1 & 0.580 & \multirow{6}{*}{0.672} & & \\
\hline & ENP2 & 0.872 & & \multirow{5}{*}{0.909} & 0.780 \\
\hline Sustainable & ENP3 & 0.862 & & & \\
\hline Development & ENP4 & 0.851 & & & \\
\hline & ENP5 & 0.891 & & & \\
\hline & SP1 & 0.784 & & & \\
\hline & SP2 & 0.536 & \multirow{3}{*}{0.482} & \multirow{3}{*}{0.816} & \\
\hline & SP3 & 0.924 & & & \\
\hline & SP4 & 0.567 & & & \\
\hline & SP5 & 0.576 & & & \\
\hline
\end{tabular}


The above table 1 has presented the results of measurement model. It has been revealed from the results that all factor loadings $>0.4$ as per Field (2013) criteria, AVE $>0.5, \mathrm{CR}>0.7$, Alpha values also >0.70 suggested by Hair et al., (2017). Two AVE values are less <0.5 but their respective CR values $>0.7$ so it does meet criteria. So, it is assumed that scales are reliable and valid.

Table 2

Regression Analysis GHRM and Economic Performance

\begin{tabular}{clcccccc}
\hline \multicolumn{1}{c}{ DV } & \multicolumn{1}{c}{ IV } & R & R2 & F & $\beta$ & $p$ & Support \\
\hline \multirow{3}{*}{ Economic } & Constant & 0.200 & 0.040 & 4.271 & & 0.002 & \\
Performance & GRSL & & & & 0.156 & 0.023 & Yes \\
& GT & & & & -0.161 & 0.029 & Yes \\
& GPE & & & & 0.119 & 0.047 & Yes \\
\hline & G Reward & & & & 0.105 & 0.047 & Yes \\
\hline
\end{tabular}

Multiple regressions were run to investigate the impact of GHRM practices upon economic performance. It is identified from results all GHRM management practices significantly plays their role upon economic performance. The Beta value of GRSL $\beta=0.156, p<0.05$, GT $\beta=-0.161$, $\mathrm{p}<0.05$, GPE $\beta=0.119, \mathrm{p}<0.05$, Green rewards $\beta=0.105, \mathrm{p}<0.05$. This means that one unit change in recruitment and selection could bring $15.6 \%$ change in sustainable development of organizations, furthermore one unit increase or decrease in the green training would be responsible for $16.1 \%$ change in sustainable development because training requires huge budget and it is difficult for new firms to arrange financial resources for the environmental training, moreover, performance appraisal also requires skills and experience therefore one percent change in green performance evaluation is responsible for $11.9 \%$ change in economic sustainable development, and $10.5 \%$ change is expected due to green rewards. From the above discussion it is evident that training and recruitment and selection are mostly responsible for bringing economic sustainability in organizations.

Table 3

Regression analysis GHRM and Environmental Performance

\begin{tabular}{llcccccc}
\hline \multicolumn{1}{c}{ DV } & \multicolumn{1}{c}{ IV } & R & R2 & F & $\beta$ & $p$ & Support \\
\hline \multirow{3}{*}{ Environmental } & Constant & 0.494 & 0.244 & 33.18 & & 0.000 & \\
Performance & GRSL & & & & 0.219 & 0.000 & Yes \\
& GT & & & & -0.061 & 0.354 & No \\
& GPE & & & & 0.160 & 0.003 & Yes \\
\hline & G Reward & & & & 0.338 & 0.000 & Yes \\
\hline
\end{tabular}

Multiple regressions analysis was run upon environmental performance and it has been presented in table 3 that except green training all GHRM practices play significant role on environmental performance. The Beta value for GRSL $\beta=0.219, \mathrm{p}<0.01$, green recruitment and selection help organizations to attract more talented and those employees who have the awareness about the environmental issues, GRSL is responsible for $21.9 \%$ change in environmental sustainability, while green training is not found significant on the other hand, green performance evaluation is responsible $16 \%$ change in environmental sustainability and highest change in environment 
is predicted by green rewards i.e. $33.8 \%$ because it motivates the employees to achieve green objectives.

Table 4

Regression analysis GHRM and social Performance

\begin{tabular}{llcccccc}
\hline \multicolumn{1}{c}{ DV } & \multicolumn{1}{c}{ IV } & R & R2 & F & $\beta$ & $p$ & Support \\
\hline & & & & & & & \\
Social & Constant & 0.172 & 0.030 & 3.140 & & 0.015 & \\
Performance & GRSL & & & & 0.025 & 0.721 & No \\
& GT & & & & -0.121 & 0.102 & No \\
& GPE & & & & 0.203 & 0.001 & Yes \\
\hline & G Reward & & & & -0.013 & 0.809 & No \\
\hline
\end{tabular}

From table 4 it is clear that only green performance evaluation play its significant role on social performance while green recruitment and selection, green training, and green rewards do not have any significant impact on social performance. In this connection, the green performance evaluation helps organizations to retain motivated staff. There is need to focus on recruitment, selection, training and rewards in organizations, so that the employees should know their social responsibility toward societies, communities and take care stakeholders' interests in effective manners.

\section{DISCUSSION}

The aim of the current study was to investigate the role of green human resources management practices upon sustainable performance. For this purpose survey was used. For this purpose those organizations that have awareness and initiated the green activities were selected for data collection. General Managers, chief executive officers and director HR were selected as unit of analysis. It has been assessed from findings that green practices could bring positive change in economic performance of organizations; furthermore, green practices could bring significant variation in environmental performance of firm except green training. Moreover, green HRM practices are not held responsible for social performance except green performance appraisal. Therefore, it is recommended that inclusion of corporate social responsibility is crucial to add in the model in future studies so that social performance might be enhanced. The findings of the current study are consistent with findings of Yusliza et al. (2020); Anwar et al. (2020); Mas (2019). They reported that green human resource practices are able to attain competitive advantage and sustainable performance. The findings of study got support from Yusliza et al. (2020) that green human resource management practices can help organizations to reduce cost, time, produce ecological friendly products and services which are better for environment and health of general public.

Green recruitment and selection help organizations to attract competent employees (Yusliza et al., 2020) while by green training values can be added to enhance performance of employees (Yon et al., 2019) while performance evaluation needs the expertise and experience to retain talented staff (Anwar et al., 2020) and green rewards are found responsible to increase the job satisfaction, motivation, sustainable performance and competitive advantage (Mas, 2019). Malik et al. (2020) conducted study on green HRM and sustainable performance also reported that green HRM and its attributes are significantly related with sustainable performance and 
its dimensions such as economic, environmental and social performance. Moreover, Higgins and Coffey (2016) also reported the significant and positive effect of green recruitment and selection, green training and development, green performance appraisal and green rewards on the sustainable organizational performance. Moreover, Yusoff et al. (2018) also reported the significant impact of green initiatives upon the sustainability. Furthermore, Rayner and Morgan (2018) also claimed the significant role of GHRM on sustainability. Hence all 3 hypotheses are accepted.

\section{CONCLUSION}

From findings it is concluded that organizations has to focus on their customers and stakeholder requirement if they want to survive in the market for long term. It is also concluded that green activities can enhance image of corporation in eyes of customers and societies as well (Akhtar et al., 2018). Therefore, health organizations in order to improvise their operations, quality of services and satisfaction of supply chain partners, stakeholders, customers, consumers and the employees should initiate their green objectives under green shared vision to attain economic, environmental and social sustainability (Guerci, Longoni \& Luzzini, 2016). In spite of several contributions the existing study has few limitations as well. The sample size used in the current study was small it is recommended that future studies may use big sample size more than 500 . The second limitation of this study is single method of data collection and it is source of biasness so, future researchers may use mix methods or longitudinal studies or may add archival study to reduce biasness. Third limitation is direct link between predictor and criterion variables. It is suggested that researchers must add some mediators and moderators and investigate complex models.

\section{REFERENCES}

Ahmad, S. (2015) Green human resource management: Policies and practices. Cogent Business Management, 2, 1030817.

Akhtar, P., Khan, Z., Frynas, J., Tse, Y., \& Nicholson, R. (2018). Essential micro-foundations for contemporary business operations: Top management tangible competencies, relationship-based business networks and environmental sustainability. British Journal of Mnaagement, 29, 43-62.

Anwar, N., Mahmood, N., Yusliza, M., Ramayah, T., Faezah, J, \& Khalid, W. (2020). Green human resource management for organisational citizenship behaviour towards the environment and environmental performance on a university campus. Journal of Clean Production, 256, 120401.

Alkhateeb, T.T.Y. (2018) Green human resource management, financial markets and pollution nexus in Saudi Arabia. The International Journal of Energy \& Economic Policy, 8, $33-36$.

Bombiak, E., \& Marciniuk-Kluska, A. (2018) Green human resource management as a tool for the sustainable development of the enterprises: The Polish young company experience. Sustainability, 10, 1739.

DalMas, F. (2019) The relationship between intellectual capital and sustainability: An analysis of practitioner's thought. In Intellectual Capital Management as a Driver of Sustainability; Springer: Berlin, Germany,; pp. 11-24.

Guerci, M., Longoni, A., \& Luzzini, D. (2016). Translating stakeholder pressures into environmental performance-the mediating role of green hrm practices. International Journal of Human Resource Management, 27, 262-289. 
Higgins, C., \& Coffey, B. (2016) Improving how sustainability reports drive change: A critical discourse analysis. Journal of Cleaner Production, 136, 18-29.

Malik, S. Y., Cao, Y., Mughal, Y. H., Kundi, G. M., Mughal, M. H., \& Ramayah T. (2020). Pathways towards Sustainability in Organizations: Empirical Evidence on Role of Green Human Resource Management Practices and Green Intellectual Capital. Sustainability. 12(8):3228.

Mtutu, P., \& Thondhlana, G. (2016). Encouraging pro-environmental behaviour: Energy use and recycling at Rhodes university, South Africa. Habitat International, 53, 142-150.

Rayner, J., \& Morgan, D. (2018). An empirical study of 'green'workplace behaviours: Ability, motivation and opportunity. Asia Pacific Journal of Human Resource, 56, 56-78

Shahzad, H., Kumar, R., Zakaria, M., \& Hurr, M. (2017) Carbon emission, energy consumption, trade openness and financial development in Pakistan: A revisit. Renewable \& Sustainable Energy Reviews, 70, 185-192.

Sekaran, U., \& Bougie, R. (2016.) Research Methods for Business: A Skill Building Approach; John Wiley \& Sons: Hoboken,NJ, USA,

Taylor, K. M., \& Vachon, S. (. 2018) Empirical research on sustainable supply chains: IJPR's contribution and research avenues. International Journal of Production Research, 56, 950-959.

World Commission on Environment and Development (WCED), Brundtland, G.H. Presentation of the Report of the World Commission on Environment and Development to the Commission of the European Communities, the EC and EFTA Countries. 5 May 1987, Brussels; World Commission on Environment and Development: Brussels, Belgium, 1987.

Yong, J. Y., Yusliza, M. Y., Ramayah, T., Jabbour, J., Sehnem, S., \& Mani, V. (2019). Pathways towards sustainability in manufacturing organizations: Empirical evidence on the role of green human resource management. Business Strategy and the Environment. 10, 89-97.

Yusliza, M., Yong, J. Y., Tanveer, M. I., Ramayah, T., Faezah, J. N., Muhammad, Z. (2020). A structural model of the impact of green intellectual capital on sustainable performance. Journal of Cleaner Production, 249, 119334.

Yusoff, Y. M., Omar, M. K., Zaman, M., \& Samad, S. (2019). Do all elements of green intellectual capital contribute toward business sustainability? Evidence from the Malaysian context using the partial least squares method, Journal of Cleaner Production, 234, 626-637.

Yusoff, Y. M., Nejati, M., Kee, D. M. H., \& Amran, A. (2018) Linking green human resource management practices to the environmental performance in hotel industry. Global Business Review. 136, 44-50

Yusliza, M. Y., Othman, N. Z., \& Jabbour, C. J. C. (2017) Deciphering the implementation of green human resource management in emerging economy. Journal of Management Development. 29, 66-73.

Zhao, J.; Liu, H.; Sun, W. (2020) How proactive environmental strategy facilitates environmental reputation: Roles of green human resource management and discretionary slack. Sustainability, 12, 763 . 